\title{
Review
}

\section{Apo2L/TRAIL and its death and decoy receptors}

\author{
HN LeBlanc ${ }^{1}$ and A Ashkenazi ${ }^{*}, 1$ \\ 1 Department of Molecular Oncology, Genentech, Inc., 1 DNA Way, South San \\ Francisco, CA 94080, USA \\ * Corresponding author: A Ashkenazi, Department of Molecular Oncology, \\ Genentech, Inc., 1 DNA Way, South San Francisco, CA 94080, USA. \\ Fax: 650225 6127; E-mail: aa@gene.com
}

Received 21.5.02; accepted 28.10.02

Edited by G Melino

\begin{abstract}
Apo2 ligand or tumour necrosis factor-related apoptosisinducing ligand (Apo2L/TRAIL) is one of the several members of the tumour necrosis factor (TNF) gene superfamily that induce apoptosis through engagement of death receptors (DRs). Apo2L/TRAIL interacts with an unusually complex receptor system of two DRs and three decoys. This protein has garnered intense interest as a potential candidate for cancer therapy because as a trimer it selectively induces apoptosis in many transformed cells but not in normal cells. While much of the early characterisation of Apo2L/TRAIL and its receptors relied on overexpression studies, recent work using untransfected cells has clarified how endogenous proteins transmit apoptotic signals from this ligand. In this review, we focus on the apoptotic signalling pathways stimulated by Apo2L/TRAIL and summarise what is known about its physiological role.

Cell Death and Differentiation (2003) 10, 66-75. doi:10.1038/ sj.cdd. 4401187
\end{abstract}

Keywords: apoptosis; caspases; TNF superfamily; Bcl-2; bax

Abbreviations: Apo2L, apoptosis ligand 2; TRAIL, TNF-related apoptosis-inducing ligand; TNF, tumour necrosis factor; DR, death receptor; DcR, decoy receptor; DISC, death-inducing signalling complex; FADD, Fas-associated death domain; ALPS, autoimmune lymphoproliferative syndrome; FasL, fas ligand; IAP, inhibitor of apoptosis protein; LZ, leucine zipper; MMR, mismatch repair

\section{Identification of Apo2L/TRAIL and its Receptors}

Apo2 ligand or tumour necrosis factor-related apoptosisinducing ligand (Apo2L/TRAIL) was originally cloned by virtue of its sequence homology to Fas/Apo1 ligand (FasL) and the tumour necrosis factor (TNF) superfamily. ${ }^{1,2}$ Various studies show that Apo2L/TRAIL potently induces apoptosis in a broad range of cancer cell lines, but not in many normal cells. ${ }^{3,4}$
The identification of two signalling receptors of the TNF receptor (TNFR) gene superfamily that bind Apo2L/TRAIL pointed to the mechanism for induction of apoptosis by this ligand: DR4 ${ }^{5}$ (death receptor 4 or TRAIL-R1) and DR5 (TRAIL-R2) ${ }^{6-12}$ both contain a conserved death domain motif (Figure 1). The complexity of Apo2L/TRAIL's receptor system is unprecedented: in addition to the two DRs, three other receptors bind to Apo2L/TRAIL, and appear to act as 'decoys'. DcR1 (TRAIL-R3) ${ }^{5,6,8,13,14}$ and DcR2 (TRAIL-R4) ${ }^{15-17}$ have close homology to the extracellular domains of DR4 and DR5. DcR2 has a truncated, nonfunctional death domain, while DcR1 lacks transmembrane and death domains. Both receptors are therefore incapable of transmitting an apoptosis signal. A fifth binding protein, the soluble TNFR family member osteoprotegerin (OPG), binds Apo2L/TRAIL but has lower affinity at physiological temperature. ${ }^{18,19}$.

Apo2L/TRAIL is expressed as a type 2 transmembrane protein, but its extracellular domain can be proteolytically cleaved from the cell surface. Like most other TNF family members, Apo2L/TRAIL forms a homotrimer that binds three receptors, each at the interface between two of its subunits $^{20,21}$ (Figure 2). A Zn atom bound by cysteines in the trimeric ligand is essential for optimal biological activity. ${ }^{22,23}$ Because of this unique structural feature, the method of preparing recombinant soluble ligand may be important for evaluating results: some preparations lacking the $\mathrm{Zn}$ have reduced solubility and tend to aggregate, perhaps explaining the reported toxicity of certain Apo2L/TRAIL preparations to human hepatocytes. ${ }^{24,25}$ Untagged, trimeric Apo2L/TRAIL containing stoichiometric $\mathrm{Zn}$ at doses up to $100 \mu \mathrm{g} / \mathrm{ml}$ did not induce significant cell death in either human or cynomolgous monkey hepatocytes ${ }^{25}$ or in human keratinocytes. ${ }^{26}$ Aggregated or antibody crosslinked forms of Apo2L/TRAIL can transduce a stronger signal through the DRs in certain cell types. Some cells including Jurkat T cells, hepatocytes and keratinocytes are resistant to the trimeric ligand but sensitive to these higher-order oligomeric forms.

\section{Apo2L/TRAIL DISC}

The earliest biochemical event following engagement of DRs by their ligand is the recruitment of proteins to the intracellular death domain of the receptor to form a structure known as the death-inducing signalling complex (DISC). ${ }^{27}$ It is now firmly established that in untransfected cells the Apo2L/TRAIL DISC resembles that of Fas in that the adaptor protein Fasassociated death domain (FADD) and the apoptosis initiator caspase-8 are recruited to DR4 and/or DR5 shortly after addition of Apo2L/TRAIL ${ }^{28-30}$ (Figure 3). Unlike the TNFR1 DISC, TRADD and RIP do not appear to be present in the native Apo2L/TRAIL DISC. ${ }^{28,29}$ Apo2L/TRAIL can trigger apoptosis independently through DR4 or DR5. ${ }^{28,29}$ In cells expressing both receptors, DR4 and DR5 can form 


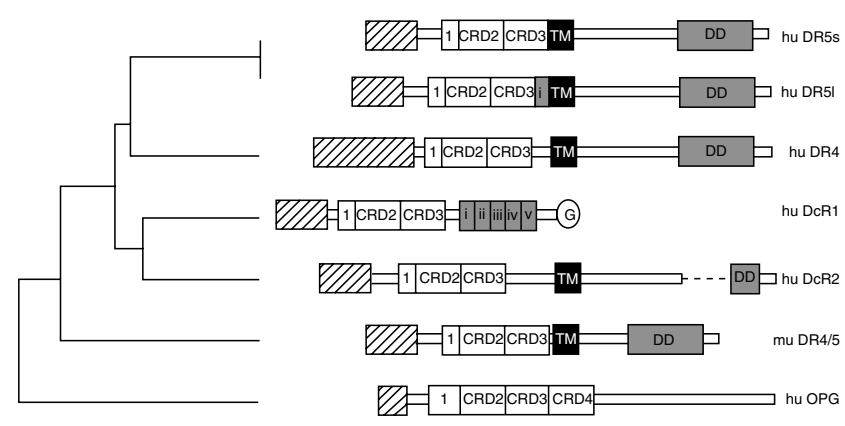

Figure 1 Phylogenetic and structural relation between Apo2L/TRAIL-binding receptors. Hatched boxes represent signal sequences, the cysteine-rich domains (CRD) are shown numbered by analogy to the TNFR1 structure, and the death domains (DD) are indicated by shading. The long splice form of DR5 contains one of the five pseudorepeats found in DcR1 (roman numerals). TM: transmembrane domain, G: glycophospholipid anchor

heterocomplexes, ${ }^{28}$ but it remains to be determined whether these have a specific signalling function. Once recruited to the DISC caspase-8 autoactivates by proteolysis, as evidenced by the presence of cleaved prodomain fragments that persist in the DISC.

Caspase-10 is an initiator caspase, found in primates but not rodents, with high homology to caspase-8. The importance of caspase-10 in the Apo2L/TRAIL DISC has been controversial. Lymphocytes from ALPS II patients bearing a caspase-10 mutation were resistant to Apo2L/TRAIL killing, ${ }^{31}$ yet several groups were unable to show endogenous caspase-10 in the native Apo2L/TRAIL DISC. ${ }^{29,30}$ The discrepancy was resolved by evidence that many commercially available polyclonal antibodies, raised against a specific isoform of caspase-10, crossreact with the similarly sized Hsp60 protein. $^{32}$ Experiments with several carefully characterised caspase-10-specific antibodies demonstrated that endogenous caspase-10 is recruited and activated in the Apo2L/TRAIL DISC (as well as in the FasL DISC), and that it is capable of transmitting an apoptosis signal in the absence of caspase- $8 .^{32}$ Consistent with the data from APLS II patients, a survey of lung and breast carcinoma cell lines showed that loss of caspase-10, often post-transcriptionally, was much more common than loss of caspase-8, suggesting the former might have a more significant role in resistance to apoptosis in cancer cells. $^{32}$

\section{Contextual Importance of the Bcl-2 Family in Apoptosis Induction by Apo2L/TRAIL}

Apoptosis initiated through DRs depends on cell-extrinsic signals (i.e. engagement of death ligands) that result in DISC formation and proteolytic activation of caspase-3 by caspase8 or -10 . Cell-intrinsic cues such as DNA damage trigger apoptosis through a mitochondrial pathway (Figure 4a). When the cell-intrinsic apoptosis pathway is stimulated, the $\mathrm{Bcl}-2$ family member Bax translocates to the mitochondria, the mitochondrial transmembrane potential dissipates, and cytochrome $c$ is released to the cytosol, activating caspase- 9 and subsequently the effector caspases. ${ }^{33}$ Proapoptotic members of the Bcl-2 family such as Bax or its homologue Bak are counteracted by the antiapoptotic family members Bcl-2 or $\mathrm{Bcl}-\mathrm{X}_{\mathrm{L}} \cdot{ }^{34} \mathrm{~A}$ subset of the $\mathrm{Bcl}-2$ family, proteins such as Bim, Bid, PUMA and NOXA, contain only one of the four Bcl-2 homology domains $(\mathrm{BH} 3)$ common to the rest of the family. BH3-only proteins interact with proapoptotic Bcl-2 family members to augment their activity. When cleaved by caspase-8, Bid translocates to the mitochondria where it activates Bax and Bak, providing a mechanism for crosstalk between the DRs and the intrinsic pathway. ${ }^{35,36}$

In addition to the proteolytic caspase cascade, caspase activity is further regulated by the inhibitors of apoptosis (IAP). The best characterised is XIAP, which inhibits caspase- 9 and caspase-3 not by interacting with their zymogens but through binding to their intermediate and fully cleaved forms. ${ }^{37} \mathrm{Smac} /$ DIABLO is released from the mitochondria of apoptotic cells and accelerates cell death activation by displacing XIAP from the caspases. ${ }^{38,39}$

In studies of Fas-induced apoptosis, Bcl-2 or Bcl- $\mathrm{X}_{\mathrm{L}}$ overexpression defines two types of cells with a differential dependence on the mitochondrial pathway. ${ }^{40}$ In Type I cells, $\mathrm{Bcl}-2$ or $\mathrm{Bcl}-\mathrm{X}_{\mathrm{L}}$ block all the mitochondrial changes associated with cell death, but do not prevent Fas-initiated apoptosis. In these cells, robust DISC formation and processing of caspase- 8 are thought to activate the effector caspases directly, committing the cells to death despite the lack of mitochondrial pathway participation. In mouse double knockouts of Bax and Bak, thymocytes remain sensitive to Fas despite the inactivation of the intrinsic pathway. ${ }^{41}$ Type II cells, on the other hand, cannot die in response to Fas activation when $\mathrm{Bcl}-2$ or $\mathrm{Bcl}-\mathrm{X}_{\mathrm{L}}$ is overexpressed to block the mitochondrial cell death pathway. Hepatocytes are an example of cells that become resistant to Fas-induced apoptosis in vivo when Bid, or both Bax and Bak, are deleted. ${ }^{42}$

In Bcl-2/X $\mathrm{X}_{\mathrm{L}}$ overexpression systems, Apo2L/TRAIL-dependent killing does not necessarily fit the Type I/II model described for Fas. In the prototypical Type II cell lines, Jurkat and CEM, transfection of Bcl-2 blocked activation of caspase8 after Fas stimulation, ${ }^{40}$ but not after addition of Apo2L/ TRAIL. ${ }^{43}$ Furthermore, while Fas-dependent apoptosis was completely prevented by $\mathrm{Bcl}-2 / \mathrm{X}_{\mathrm{L}}$ overexpression in these cell lines, ${ }^{40}$ Apo2L/TRAIL killing was not, even though cytochrome $c$ was not released to the cytosol and depolarisation of the mitochondrial membrane was delayed. ${ }^{43,44}$ In HL60 or HCT116 cells, however, overexpression of $\mathrm{Bcl}-2 / \mathrm{X}_{\mathrm{L}}$ blocked Apo2L/TRAIL-triggered apoptosis. ${ }^{45,46}$ Since the difference between Types I and II cells may lie at the level of DISC formation, it could be that the requirement for the mitochondrial pathway is not merely a property of a given cell, but depends also on which DR is mediating the apoptotic signal.

Gene ablation studies are perhaps a more definitive system than $\mathrm{Bcl}-2 / \mathrm{X}_{\mathrm{L}}$ overexpression for examining the requirement for the intrinsic pathway in Apo2L/TRAIL-initiated cell death. Three recent papers using a colon carcinoma cell line with Bax deletion $^{47-49}$ or selected for Bax mutation ${ }^{47}$ showed that Bax was absolutely required for Apo2L/TRAIL-mediated apoptosis, even though Bak was expressed in these cells. ${ }^{47}$ Early events triggered by Apo2L/TRAIL, such as DISC formation, caspase-8 activation and Bid cleavage were not dependent on Bax, but mitochondrial depolarisation, cytochrome $c$ release 


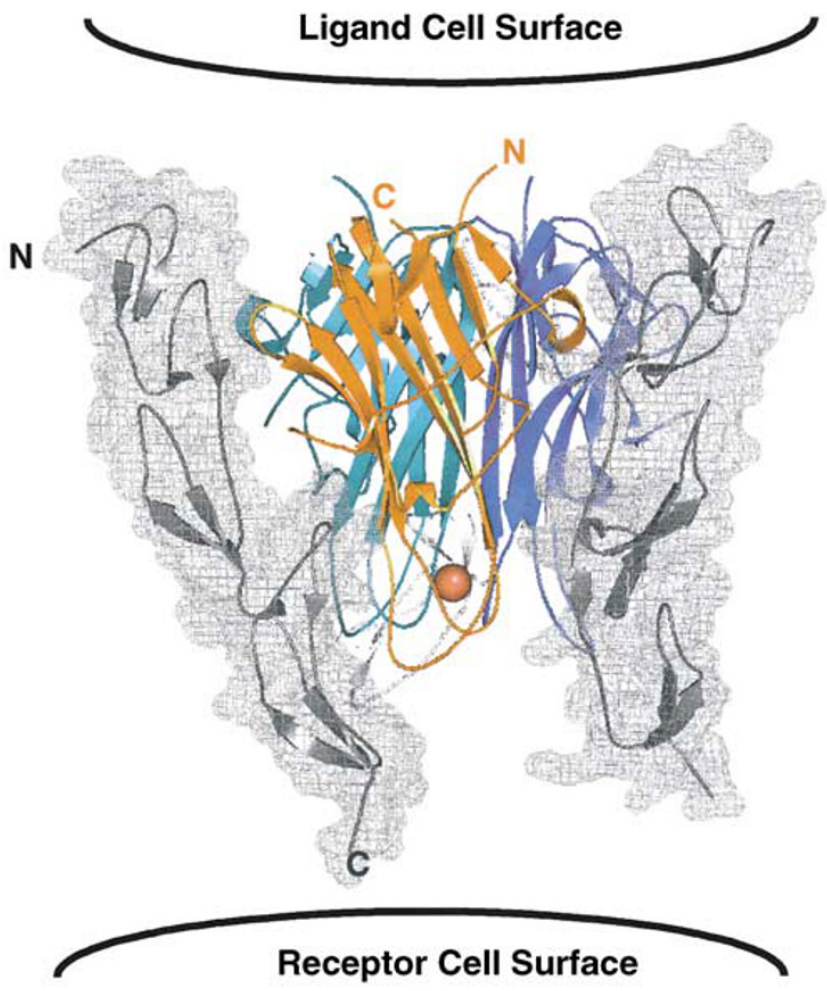

Figure 2 Structure of Apo2L/TRAIL in complex with the extracellular domain of DR5. The receptor subunits are shown in grey, and the three Apo2L/TRAIL subunits are coloured. The single $\mathrm{Zn}$ is represented as a red sphere

and activation of caspase- 9 were blocked in Bax-deficient cells. ${ }^{47,48}$ Thus, in these cells, the intrinsic pathway was required for Apo2L/TRAIL-mediated apoptosis, and Bax was essential for the mitochondrial events.

Of note, caspase- 3 was cleaved to its p24 intermediate form in Bax-deficient cells after Apo2L/TRAIL stimulation. ${ }^{48}$ Although this is contrary to the Type II cell model, which holds that the mitochondrial pathway is required to activate caspase- 9 and thus caspase- 3 , it is not necessarily surprising given that caspase- 8 was active and could process Bid. ${ }^{47-49}$ Caspase- 9 processes caspase- 3 at the same cleavage site as caspase-8, so it may be redundant in caspase-3 activation. Full activation of the p24 form of caspase- 3 is autocatalytic, a step that is blocked by $\mathrm{XIAP}^{37}$ (Figure $4 \mathrm{~b}$ ). Bax deficiency was bypassed by cytosolic expression of Smac/DIABLO, which antagonises XIAP. ${ }^{48}$ Therefore, it seems that in addition to promoting the activation of caspase-9, the mitochondrial pathway contributes to Apo2L/TRAIL-induced apoptosis by releasing Smac/DIABLO to the cytosol and relieving XIAP inhibition of caspase-3.

Thus, at least in some cells with Bax deficiency, the intrinsic pathway is essential for Apo2L/TRAIL to induce apoptosis. Other cells, even some that are Type II with respect to Fasinduced apoptosis, are apparently independent of this pathway.

\section{Modulators of Apo2L/TRAIL Signalling}

It is not fully understood why normal cells and certain tumour cells are resistant to Apo2L/TRAIL. Several potential mechan- isms have been proposed, but no consistent correlations or causal connections have been shown.

One downstream effector of the mitochondrial apoptotic pathway is Smac/DIABLO, which relieves XIAP repression of caspase-3. A comparison of Apo2L/TRAIL-sensitive and resistant melanoma cell lines showed a strong correlation between sensitivity and effector caspase activity. ${ }^{50}$ Although levels of XIAP did not differ between cell lines, association between XIAP and cleavage products of the caspase-3 zymogen correlated with Apo2L/TRAIL resistance. Apo2L/ TRAIL-sensitive cell lines released more Smac/DIABLO to the cytosol, so one factor contributing to resistance in some cells may be a decreased propensity to release Smac/DIABLO in response to Apo2L/TRAIL, leading to insufficient activation of effector caspases. Why the propensity varies remains to be determined.

Burns and El-Deiry ${ }^{46}$ screened for genes in a human placental cDNA library that could confer Apo2L/TRAIL resistance to a sensitive colon carcinoma cell line. They recovered only the short form of the cellular FLICE-inhibitory protein $\left(\mathrm{c}-\mathrm{FLIP}_{\mathrm{S}}\right.$ ) and $\mathrm{Bcl}-\mathrm{X}_{\mathrm{L}}$. C-FLIP has homology to caspase- 8 and caspase-10, but lacks protease activity. ${ }^{51}$ It is therefore thought that c-FLIP recruitment to the DISC in place of the initiator caspases blocks their activation. Some overexpression studies point to C-FLIP as an inhibitor of caspase-8 activation at the Apo2L/TRAIL DISC, ${ }^{52,53}$ and others have found correlations between FLIP levels and Apo2L/TRAIL resistance. ${ }^{54,55}$ Other studies, however, failed to find such a correlation. ${ }^{50,56}$ Thus, it remains unclear whether c-FLIP is an important determinant of Apo2L/TRAIL resistance. As discussed above, studies on the effect of Bcl$X_{L}$ overexpression on Apo2L/TRAIL sensitivity also yielded conflicting results.

Apo2L/TRAIL binds with high affinity to two receptors, DcR1 and DcR2, incapable of transmitting an apoptotic signal owing to absent or incomplete death domains. Overexpression of these receptors protects cells from apoptosis induction by Apo2L/TRAIL, suggesting that they act as 'decoys', sequestering the ligand from the signalling receptors. ${ }^{6,17}$ Many normal adult tissues express at least one of the DcRs. ${ }^{6,15}$ Surveys of cancer cell lines and tumours did not reveal correlations between DcR expression and Apo2L/TRAIL resistance, but almost all of these studies relied on detecting mRNA $^{54,57,58}$ rather than looking for cell surface expression of the proteins. ${ }^{59}$ It is possible that even detection of receptors by Western blot ${ }^{45}$ may be misleading as the DcRs sometimes localise within the cell rather than at the cell surface. ${ }^{60,61}$ It is not fully understood how widespread surface expression of the decoy receptors is in tumour or normal cells, or precisely how these receptors modulate Apo2L/TRAIL signalling.

$\mathrm{NF}-\kappa \mathrm{B}$ is strongly activated shortly after TNF engagement of TNFR1, generating a prosurvival signal that must be overcome in many cell types for TNF to induce apoptosis (reviewed in Wu et al. ${ }^{62}$ ). NF- $\kappa \mathrm{B}$ reportedly induces upregulation of FLIP, Bcl- $X_{L}$ and XIAP and may exert protection against cell death through these molecules. While Apo2L/ TRAIL can also activate $\mathrm{NF}-\kappa \mathrm{B}$, stimulation is significantly attenuated and delayed, and requires high concentration of the ligand compared to that induced by TNF, suggesting that $\mathrm{NF}-\kappa \mathrm{B}$ induction by Apo2L/TRAIL may be a secondary, 


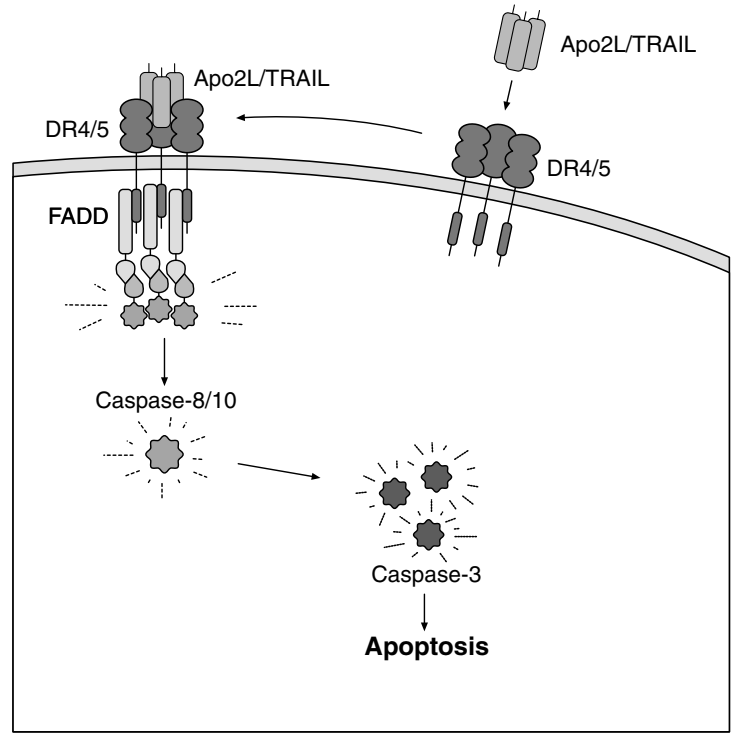

Figure 3 Apo2L/TRAIL DISC assembly. See text for details
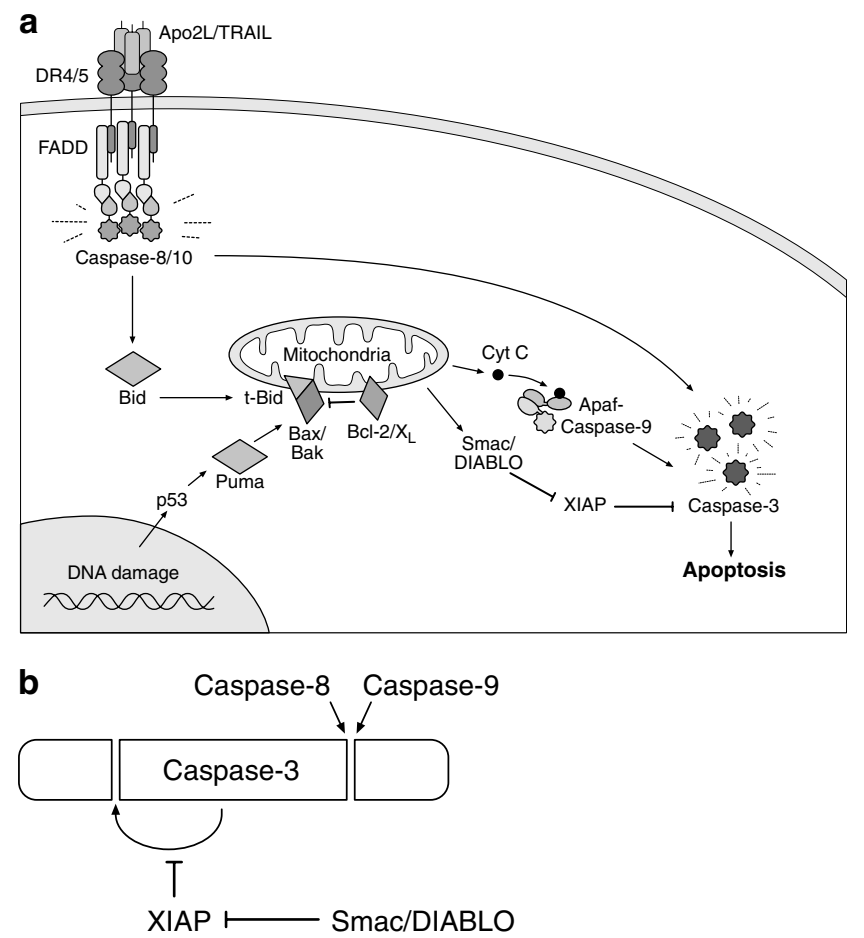

Figure 4 The apoptotic signalling cascades (a) See text for details. (b) Activation of caspase-3 is initiated by cleavage by caspase-8 or caspase- 9 to generate the small subunit and the p24 processing intermediate. Subsequent removal of the prodomain is autocatalytic and can be blocked by XIAP. This inhibition is relieved by Smac/DIABLO

indirect event. ${ }^{6}$ In a cancer cell line with high constitutive NF$\kappa \mathrm{B}$ activity, however, specific downregulation of NF- $\kappa \mathrm{B}$ by inactivation of the $\mathrm{I}-\kappa \mathrm{B}$ kinase significantly sensitised the cells to Apo2L/TRAIL. ${ }^{49}$ Thus, while Apo2L/TRAIL is unlikely to activate $\mathrm{NF}-\kappa \mathrm{B}$ directly, in some contexts this transcription factor can moderate sensitivity to this death ligand.
Other signalling pathways are likely to influence susceptibility to Apo2L/TRAIL. p53, an important mediator of apoptosis in response to DNA damage, upregulates DR5, thereby sensitising cells to Apo2L/TRAIL. ${ }^{63}$ Protein kinase $C,{ }^{64,65}$ MAP kinase ${ }^{66}$ and $\mathrm{Akt}^{67,68}$ activity have also been reported to affect Apo2L/TRAIL activity, although the mechanisms are unclear at present.

In summary, DcRs, IAPs, FLIP and $\mathrm{Bcl}-2 / \mathrm{X}_{\mathrm{L}}$ appear to contribute to resistance when overexpressed, but a full understanding of their respective biological roles in unmanipulated cells requires further examination. NF- $\kappa \mathrm{B}, \mathrm{p} 53$ and various kinase signalling pathways may also modulate Apo2L/TRAIL sensitivity, especially in the context of transformed cells in which many of these activities are aberrant. The interactions of these signals may be complex and the important determinants of Apo2L/TRAIL sensitivity or resistance remain to be identified.

\section{Does Apo2L/TRAIL Have Additional, Nonapoptotic Signalling Functions?}

Kumar-Sinha et al. ${ }^{69}$ looked directly at effects on transcription mediated by Apo2L/TRAIL signalling using microarray analysis. While informative, one important caveat to their results is that significant changes in mRNA levels in response to Apo2L/ TRAIL occurred only when the protein synthesis inhibitor cycloheximide was included. Under these conditions (and including a pan-caspase inhibitor to prevent apoptosis), Apo2L/TRAIL induced three clusters of genes over time. The early cluster, induced at $1-4 \mathrm{~h}$, includes primarily genes that have not been well characterised with respect to apoptosis. After $4 \mathrm{~h}$ of treatment, many NF- $\kappa$ B-regulated genes were induced and remained high (the intermediate cluster). This delayed activation of $\mathrm{NF}-\kappa \mathrm{B}$, relative to the rapid activation in response to TNF and the timing of Apo2L/TRAIL-induced cell death, further supports the notion that NF- $\kappa$ B activation is unlikely to be as important in Apo2L/ TRAIL signalling as it is for TNF. The late cluster, genes upregulated after $16 \mathrm{~h}$ exposure to Apo2L/TRAIL, was mainly interferon (IFN)-inducible genes. Despite the presence of cycloheximide in the experimental set-up, the authors found that protein synthesis was not completely blocked, and that significant amounts of IFN- $\beta$ were synthesised after Apo2L/ TRAIL addition. These data, combined with the late time of induction of these genes, suggest that the cluster of IFNpathway-related genes is a secondary consequence of Apo2L/TRAIL exposure. Interestingly, induction of these genes was blocked when dominant-negative FADD was present.

This study is important as the only systematic examination of transcriptional signalling induced by Apo2L/TRAIL reported to date. However, the necessity to include cycloheximide and the late induction of many of the genes in a transformed cell line that would normally die within $4 \mathrm{~h}$ of Apo2L/TRAIL treatment raises the question of how relevant the results are to Apo2L/TRAIL's role in inducing apoptosis. To date, there have been no reports of how Apo2L/TRAIL affects apoptosisresistant cells. 


\section{Physiological Role for Apo2L/TRAIL}

The receptor system for Apo2L/TRAIL in mice is markedly less complex than in humans. There is only one signalling receptor, homologous to both DR4 and DR5 (Figure 1), and so far no decoys have been identified. ${ }^{70}$ The biology of Apo2L/ TRAIL may therefore differ significantly between the two species. Nonetheless, the phenotype of an Apo2L/TRAIL mouse knockout could be very informative with respect to the normal function of this death ligand in vivo. Apo2L/TRAIL knockout mice are viable, fertile and have no obvious haematological defects, ${ }^{71}$ suggesting that this death ligand does not have an essential developmental function. Studies with these mice confirm earlier reports of the importance of Apo2L/TRAIL in immune surveillance.

In the mouse, Apo2L/TRAIL is expressed on liver natural killer (NK) cells, but not on other lymphocytes isolated from liver or spleen. ${ }^{72}$ Blocking Apo2L/TRAIL partially prevents liver NK cell cytotoxicity in vitro, and dramatically increases liver metastasis of Apo2L/TRAIL-sensitive cell lines in vivo. Both Apo2L/TRAIL expression and its contribution to preventing liver metastases depend on IFN- $\gamma$ signalling (see below). Follow-up experiments show Apo2L/TRAIL is important in reducing the incidence of fibrosarcomas induced by low doses of the carcinogen methylcholanthrene. ${ }^{73}$ Furthermore, these studies show that tumours are much more likely to be sensitive to Apo2L/TRAIL if they arise in the presence of Apo2L/TRAIL blocking antibodies.

Cretney et al. ${ }^{71}$ confirmed many of these results in Apo2L/ TRAIL-deficient mice. Cytotoxicity of liver but not spleen NK cells is reduced whereas liver metastases, tumour growth of allografts in the mammary fat pad and fibrosarcoma induction by methylcholanthrene are all increased in the absence of Apo2L/TRAIL expression. Where it was directly compared, the magnitude of the effect of Apo2L/TRAIL gene ablation was similar to that achieved by anti-Apo2L/TRAIL blocking antibodies. Apo2L/TRAIL therefore contributes significantly to host defence against tumour initiation and metastasis in mice.

IFNs are known to have potent antitumour and antiviral effects, and mounting evidence suggests that Apo2L/TRAIL is an important effector of these activities. Both the mouse and human Apo2L/TRAIL promoters are regulated by IFN, ${ }^{74,75}$ and Apo2L/TRAIL is one of the earliest genes induced by IFN. Fibroblasts infected with human CMV and treated with IFN upregulate both Apo2L/TRAIL and its DRs. IFN potentiates the apoptotic response in infected cells by upregulating Apo2L/TRAIL on neighbouring uninfected cells while simultaneously downregulating the DRs, making CMV-infected cells differentially more sensitive to apoptosis induced by the ligand.$^{76}$ Similar differential effects on target and effector cells are seen when monocytes are treated with IFN: Apo2L/TRAIL is rapidly upregulated and DR5 downregulated. The monocytes become resistant to Apo2L/TRAIL and acquire antitumour cytotoxicity that is dependent on the ligand. ${ }^{77}$ In addition, IL-2 stimulation induces Apo2L/TRAIL in human NK cells, which use the ligand to kill tumour cell targets. ${ }^{78}$

Apo2L/TRAIL is not found on the surface of resting peripheral blood T (PBT) cells, but is dramatically induced when PBT cells are stimulated with anti-CD3 antibodies in the presence of $\mathrm{IFN}^{79}$ These stimulated PBT cells have enhanced cytotoxicity against transformed cell lines that is Apo2L/TRAIL-dependent. The antitumour effects of IFN on multiple myeloma (a plasma B cell malignancy) are also associated with rapid upregulation of Apo2L/TRAIL, and are blocked by a dominant negative form of DR5. ${ }^{80}$

In human bone marrow-derived dendritic cells, cell surfaceexpressed Apo2L/TRAIL cooperates with other death ligands to induce apoptosis in cancer cells. ${ }^{81}$ Apo2L/TRAIL alone accounts for the cytotoxicity of measles virus-infected dendritic cells. ${ }^{82}$ In this case, Apo2L/TRAIL was primarily intracellular, but blocking this ligand specifically prevented cytotoxicity. T-cell lines and normal T-cell blasts also have significant intracellular Apo2L/TRAIL in multivesicular bodies $^{83}$. Activation with anti-CD59 antibodies specifically stimulates secretion of the transmembrane form of Apo2L/ TRAIL in microvesicles that have cytotoxic activity against Jurkat cells. Apo2L/TRAIL can thus be released from cells either as a soluble protein through proteolytic cleavage from the cell surface or by secretion of the transmembrane form of the ligand on vesicles.

In addition to Apo2L/TRAIL's contribution to immune surveillance, which is consistent with its known proapoptotic activity, Apo2L/TRAIL inhibits autoimmune inflammation in experimentally induced rheumatoid arthritis ${ }^{84}$ and multiple sclerosis. ${ }^{85}$ Intriguingly, these effects do not appear to be associated with induction of apoptosis in infiltrating lymphocytes. It will be interesting to investigate whether Apo2L/ TRAIL knockout mice have a greater propensity to develop autoimmune disease in response to experimental immunisation.

Apo2L/TRAIL thus mediates a significant part of the antitumour and antiviral cytotoxicity of dendritic cells, monocytes, NK and T cells, often augmented by IFN-regulated expression of this ligand and its DRs. Apo2L/TRAIL may therefore be an important innate effector molecule in immune surveillance. Additionally, Apo2L/TRAIL might function to keep inflammatory lymphocytes in check to prevent autoimmune disease.

\section{Therapeutic Potential}

Apoptosis induction in response to cell damage usually requires function of the tumour suppressor p53, which engages the cell-intrinsic apoptotic signalling pathway. In most human cancers, tumour progression as well as conventional treatments eventually select for tumour cells in which p53 is inactivated, resulting in resistance to therapy. DRs can instruct tumour cells to commit apoptotic suicide independently of p53 (Figure 4a). Thus, targeting of DRs in cancer might be a useful therapeutic strategy. In tumours that retain some responsiveness to conventional therapy, DR engagement in combination with chemotherapy or radiation might lead to synergistic apoptosis activation, as well as reduce the probability that tumour cells resistant to either type of agent will emerge. In tumours that have lost p53 function, DR targeting might help circumvent resistance to chemotherapy and radiotherapy.

Recombinant soluble Apo2L/TRAIL induces apoptosis in a variety of cancer cell lines regardless of p53 status. This 
includes cell lines derived from cancers of the colon, lung, breast, prostate, pancreas, kidney, central nervous system and thyroid, as well as from leukaemia and multiple myeloma. Indeed, Apo2L/TRAIL is effective at inducing apoptosis in most multiple myeloma patient samples regardless of their resistance or sensitivity to chemotherapeutic drugs, ${ }^{86}$ or prior exposure to chemotherapy. ${ }^{59}$ In mouse models, Apo2L/ TRAIL demonstrated remarkable efficacy against tumour xenografts of colon carcinoma, ${ }^{87,88}$ breast carcinoma ${ }^{4}$, multiple myeloma, ${ }^{86}$ or glioma ${ }^{89,90}$ cell lines. Moreover, combinations of Apo2L/TRAIL and certain DNA-damaging drugs ${ }^{3,91}$ or radiotherapy ${ }^{92}$ exerted synergistic antitumour xenograft activity.

Like Apo2L/TRAIL, monoclonal antibodies that functionally engage DR4 or DR5 also display antitumour activity in certain xenograft studies. ${ }^{93,94}$ These include protoagonistic antibodies, which show agonistic activity upon crosslinking through the $\mathrm{Fc}$ domain, ${ }^{93}$ and antibodies that appear to possess intrinsic agonistic activity; ${ }^{94}$ however, this intrinsic activity may be caused by the presence of antibody aggregates, as is the case for anti-Fas/APO-1 antibodies. ${ }^{95}$ Both types of antibody exhibit apoptosis-mediated antitumour efficacy in xenograft models. ${ }^{93,94}$

Various recombinant versions of human Apo2L/TRAIL have been generated. One version contains Apo2L/TRAIL amino acids 114-281 fused to an amino-terminal polyhistidine tag. ${ }^{1}$ A second variant contains amino acids 95-281 fused amino terminally to a modified yeast Gal-4 leucine zipper (LZ) that promotes trimerisation of the ligand. ${ }^{4} \mathrm{~A}$ third version contains residues 95-281 fused to an amino-terminal 'Flag' epitope tag; crosslinking of this tagged protein with anti-Flag antibodies enhances its activity against certain cell lines such as Jurkat $\mathrm{T}$ leukaemia. ${ }^{23}$ Currently, a fourth recombinant version of the ligand probably is the most preferred for clinical application: it contains amino acids 114-281 of human Apo2L/ TRAIL without any added exogenous sequences. ${ }^{87}$ This latter version is therefore the least likely to be immunogenic in human patients. The production of this version has been optimised by the addition of $\mathrm{Zn}$ and reducing agent to the cell culture media and extraction buffers, and by formulation of the purified protein at neutral $\mathrm{pH}^{25,88}$

Most normal human cell types tested to date, including epithelial, endothelial, fibroblastic, and smooth muscle cells, are refractory to the nontagged, optimised version of Apo2L/ TRAIL. ${ }^{3,25}$ Some normal cell types, namely astrocytes, ${ }^{3,4}$ hepatocytes, ${ }^{24,25}$ and keratinocytes, ${ }^{26}$ are resistant to this optimised ligand version, but show significant sensitivity to apoptosis induction by nonoptimised or antibody-crosslinked variants of the ligand. One potential explanation for this difference is that commitment of these normal cells to apoptosis might require high-order multimerisation of DR4 and DR5. The versions of the ligand that are tagged and not optimised for $\mathrm{Zn}$ content can have a low solubility and tend to aggregate and/or precipitate at high concentrations, as does the antibody-crosslinked ligand. Therefore, these preparations may over-multimerise DRs, leading to a signal that surpasses the high threshold for apoptosis activation in the normal cells. A report comparing Flag-tagged Apo2L/TRAIL in crosslinked or noncrosslinked form suggested that DR4 is responsive to both forms of the ligand, whereas DR5 responds only to crosslinked Apo2L/TRAIL. ${ }^{96}$ However, data on the biochemical characteristics of the soluble ligand used in these experiments were not provided (for example, its $\mathrm{Zn}$ content, presence of aberrant intersubunit disulphides and of aggregates), making it difficult to assess the results. Moreover, several cell lines that express DR5 but not DR4 are efficiently killed by nontagged, Zn-bound Apo2L/TRAIL, including G55 and G142 glioblastoma cells (A.A., unpublished results).

Sensitivity to Apo2L/TRAIL requires the presence of at least one functioning DR since DR4 or DR5 can independently trigger apoptosis. No cell line expressing only DR4 has been reported, but experiments with DR4-crosslinking antibodies ${ }^{28}$ or antibodies that block DR5 ${ }^{29}$ show that DR4 can transduce an apoptotic signal. Since both DR4 and DR5 are expressed in various normal tissues and transformed cell lines, ${ }^{5-12}$ their presence, while required for Apo2L/TRAIL sensitivity, is not sufficient. Both receptors are located on chromosome $8 p,{ }^{21-22}$ a region of frequent loss of heterozygosity $(\mathrm{LOH})$ in tumours. In a low percentage of non-Hodgkin's lymphoma, ${ }^{97}$ nonsmall cell lung, ${ }^{98}$ colorectal, $^{99}$ breast, $^{100}$ and head and neck ${ }^{101}$ cancers, mutations or deletions were found that resulted in loss of both copies of DR4 or DR5. Inactivation of DR4/5 may therefore contribute to Apo2L/TRAIL resistance but only in a very small number of human cancers.

Bax-deficient derivatives of the HCT116 colon carcinoma cell line are resistant to Apo2L/TRAIL. ${ }^{46-49}$ Bax mutation frequently occurs in the $15 \%$ of gastric, colon and endometrial cancers that harbour defects in DNA mismatch repair (MMR), ${ }^{102}$ but does not appear to be common in MMRproficient cell lines and tumours. ${ }^{103,104}$ While MMR-deficient tumours are generally associated with favourable prognoses, patients whose tumours have Bax mutations have significantly shorter survival times. ${ }^{105}$ Experiments with MMRdeficient cell lines show that in such cells Apo2L/TRAIL selects for Bax mutation, and thus for Apo2L/TRAIL resistance, both in vitro and in vivo in xenograft tumour models. ${ }^{47}$ In vitro, prior exposure of Bax-deficient cells to topoisomerase inhibitors restores Apo2L/TRAIL sensitivity, probably by upregulating DR5 and more significantly, the Bax homologue Bak. Tumour xenografts derived from Bax-deficient cells are resistant to Apo2L/TRAIL alone, but respond when pretreated with CPT-11. Thus, the acquisition of Bax mutation in a therapeutic setting could contribute significantly to the development of Apo2L/TRAIL resistance in MMR-deficient tumours, but combining treatment with pre-exposure to chemotherapeutic drugs might circumvent this resistance.

Other in vivo studies show that Apo2L/TRAIL interacts positively not only with chemotherapy but also with irradiation. Breast carcinoma cells implanted in mouse mammary fat pads responded synergistically to a combination of Apo2L/ TRAIL and radiation treatment. ${ }^{92,106}$ Apo2L/TRAIL might therefore be most effective in combination with conventional cancer treatments. Experiments assessing the interaction of Apo2L/TRAIL with unconventional agents such as antibodies directed to tumour antigens or tyrosine kinase inhibitors are ongoing.

Initial studies in nonhuman primates, namely, cynomolgous monkeys and chimpanzees, show that short-term intravenous administration of nontagged, Zn-bound Apo2L/TRAIL is well 
tolerated even at very high doses. ${ }^{25,88}$ Thus, given Apo2L/ TRAIL's preferential proapoptotic activity on cancer cells over most normal cells, interest has focused on this ligand as a potential cancer therapeutic. Nevertheless, given that certain versions of Apo2L/TRAIL can induce hepatocyte apoptosis, ${ }^{24,25}$ the preclinical assessment of the ligand, as well as of other agents that target DR4 or DR5, as therapies for human patients must be performed with utmost caution.

\section{Future Directions}

Owing to its differential toxicity towards transformed versus normal cells, Apo2L/TRAIL shows promise as a potential cancer therapy agent although further preclinical safety testing is important to allay concerns about possible hepatotoxicity. Much progress has been made on elucidating the endogenous biochemical pathway leading to Apo2L/TRAILinduced apoptosis in cancer cells. Why normal cells generally resist Apo2L/TRAIL, how oncogenic transformation and perhaps infection makes them sensitive to this death ligand, and whether they respond to the ligand in other ways besides cell death is still not fully understood. Elucidating these questions will help advance a more in-depth biological understanding of this fascinating ligand-receptor system and realise its exciting therapeutic potential.

\section{Acknowledgments}

We thank Sarah Hymowitz and Allison Bruce for providing figures.

\section{References}

1. Pitti RM, Marsters SA, Ruppert S, Donahue CJ, Moore A and Ashkenazi A (1996) Induction of apoptosis by Apo-2 ligand, a new member of the tumor necrosis factor receptor family. J. Biol. Chem. 271: 12687-12690

2. Wiley SR, Schooley K, Smolak PJ, Din WS, Huang CP, Nicholl JK, Sutherland GR, Davis-Smith T, Rauch C, Smith CA and Goodwin RG (1995) Identification and characterization of a new member of the TNF family that induces apoptosis. Immunity 3: 673-682

3. Ashkenazi A, Pai R, Fong S, Leung S, Lawrence D, Marsters S, Blackie C, Chang L, McMurtrey A, Hebert A, DeForge L, Khoumenis I, Lewis D, Harris L, Bussiere J, Koeppen H, Shahrokh Z and Schwall R (1999) Safety and antitumor activity of recombinant soluble Apo2 ligand. J. Clin. Invest. 104: 155-162

4. Walczak H, Miller RE, Ariail K, Gliniak B, Griffith TS, Kubin M, Chin W, Jones J, Woodward A, Le T, Smith C, Smolak P, Goodwin RG, Rauch CT, Schuh JCL and Lynch DH (1999) Tumoricidal activity of tumor necrosis factor-related apoptosis-inducing ligand in vivo. Nat. Med. 5: 157-163

5. Pan G, O'Rourke K, Chinnaiyan AM, Gentz R, Ebner R, Ni J and Dixit VM (1997) The receptor for the cytotoxic ligand TRAIL. Science 276: 111-113

6. Sheridan JP, Marsters SA, Pitti RM, Gurney A, Skubatch M, Baldwin D, Ramakrishnan L, Gray C, Baker K, Wood WI, Goddard AD, Godowski P and Ashkenazi A (1997) Control of TRAIL-induced apoptosis by a family of signaling and decoy receptors. Science 277: 818-821

7. Screaton GR, Mongkolsapaya J, Xu XN, Cowper AE, McMichael AJ and Bell JI (1997) TRICK2, a new alternatively spliced receptor that transduces the cytotoxic signal from TRAIL. Curr. Biol. 7: 693-696

8. Schneider P, Bodmer JL, Thome M, Hofmann K, Hohller N and Tschopp J (1997) Characterization of two receptors for TRAIL. FEBS Lett. 416: 329-334

9. Pan G, Ni J, Wei YF, Yu G-L, Gentz R and Dixit VM (1997) An antagonist decoy receptor and a new death domain-containing receptor for TRAIL. Science 277: 815-818
10. McFarlane M, Ahmad M, Srinivasula SM, Fernandes-Alnemri T, Cohen GM and Alnemri ES (1997) Identification and molecular cloning of two novel receptors for the cytotoxic ligand TRAIL. J. Biol. Chem. 272: 25417-25420

11. Chaudhary PM, Eby M, Jasmin A, Bookwalter A, Murray J and Hood L (1997) Death receptor 5, a new member of the TNFR family, and DR4 induce FADD-dependent apoptosis and activate the NF- $\kappa$ B pathway. Immunity 7 : 821-830

12. Walczak H, Degli-Esposti MA, Johnson RS, Smolak PJ, Waugh JY, Boiani N, Timour MS, Gerhart MJ, Schooley KA, Smith CA, Goodwin RG and Rauch CT (1997) TRAIL-R2: a novel apoptosis-mediating receptor for TRAIL. EMBO J. 16: $5386-5397$

13. Degli-Esposti M, Smolak PJ, Walczak H, Waugh J, Huang CP, Dubose RF, Goodwin RG and Smith CA (1997) Cloning and characterization of TRAIL-R3, a novel member of the emerging TRAIL receptor family. J. Exp. Med. 186: $1165-1170$

14. Mongkolsapaya J, Cowper A, Xu XN, Morris G, McMichael A, Bell JI and Screaton GR (1998) Lymphocyte inhibitor of TRAIL: a new receptor protecting lymphocytes from the death ligand TRAIL. J. Immunol. 160: 3-6

15. Marsters SA, Sheridan JP, Pitti RM, Huang A, Skubatch M, Baldwin D, Yuan J, Gurney A, Goddard AD, Godowski P and Ashkenazi A (1997) A novel receptor for Apo2L/TRAIL contains a truncated death domain. Curr. Biol. 7: 1003-1006

16. Degli-Esposti MA, Dougall WC, Smolak PJ, Waugh JY, Smith CA and Goodwin RG (1997) The novel receptor TRAIL-R4 induces NF- $\kappa B$ and protects against TRAIL-mediated apoptosis, yet retains an incomplete death domain. Immunity 7: 813-820

17. Pan G, Ni J, Yu GL, Wei YF and Dixit VM (1998) TRUNDD, a new member of the TRAIL receptor family that antagonizes TRAIL signaling. FEBS Lett. 424: 41-45

18. Emery JG, McDonell P, Burke MC, Deen KC, Lyn S, Silverman C, Dul E, Appelbaum ER, Eichman C, DiPrinzio R, Dodds RA, James IE, Rosenberg M, Lee JC and Young PR (1998) Osteoprotegerin is a receptor for the cytotoxic ligand TRAIL. J. Biol. Chem. 273: 14363-14367

19. Truneh A, Sharma S, Silverman C, Khandekar S, Reddy M, Deen K, Mclaughlin M, Srinivasula S, Livi G, Marshall L, Alnemri E, Williams W and Doyle M (2000) Temperature-sensitive differential affinity of TRAIL for its receptors. J. Biol. Chem. 275: 23319-23325

20. Hymowitz SG, Christinger HW, Fuh G, Ultsch M, O'Connel M, Kelley RF, Ashkenazi A and de Vos AM (1999) Triggering cell death: the crystal structure of Apo2L/TRAIL in a complex with death receptor 5. Mol. Cell 4: 563-571

21. Mongkolsapaya J, Grimes JM, Chen N, Xu X-N, Stuart DI, Jones EY and Creaton GR (1999) Structure of the TRAIL-DR5 complex reveals mechanisms conferring specificity in apoptotic initiation. Nat. Struct. Biol. 6: 1048-1053

22. Hymowitz SG, O'Connel MP, Ultsch MH, Hurst A, Totpal K, Ashkenazi A, de Vos AM and Kelley RF (2000) A unique zinc-binding site revealed by a highresolution X-ray structure of homotrimeric Apo2L/TRAIL. Biochemistry 39: 633-640

23. Bodmer J-L, Meier P, Tschopp J and Schneider P (2000) Cysteine 230 is essential for the structure and activity of the cytotoxic ligand TRAIL. J. Biol. Chem. 275: 20632-20637

24. Jo M, Kim T-H, Seol D-W, Esplen JE, Dorko K, Billiar TR and Strom SC (2000) Apoptosis induced in normal human hepatocytes by tumor necrosis factorrelated apoptosis-inducing ligand. Nat. Med. 6: 564-567

25. Lawrence D, Shahrokh Z, Marsters S, Achilles K, Shih D, Mounho B, Hillan K, Totpal K, DeForge L, Schow P, Hooley J, Sherwood S, Pai R, Leung S, Khan L, Gliniak B, Bussiere J, Smith C, Strom S, Kelley S, Fox J, Thomas D and Ashkenazi A (2001) Differential hepatocyte toxicity of recombinant Apo2L/ TRAIL versions. Nat. Med. 7: 383-385

26. Qin JZ, Chaturvedi V, Bonish B and Nickoloff BJ (2001) Avoiding premature apoptosis of normal epidermal cells. Nat. Med. 7: 385-386

27. Kischkel FC, Hellbardt S, Behrmann I, Germer M, Pawlita M, Krammer PH and Peter ME (1995) Cytotoxicity-dependent APO-1 (Fas/CD95)-associated proteins form a death-inducing signaling complex (DISC) with the receptor. EMBO J. 14: 5579-5588

28. Kischkel FC, Lawrence DA, Chuntharapai A, Schow P, Kim KJ and Ashkenazi A (2000) Apo2L/TRAIL-dependent recruitment of endogenous FADD and caspase-8 to death receptors 4 and 5. Immunity 12: 611-620

29. Sprick MR, Weigand MA, Rieser E, Rausch CT, Juo P, Blenis J, Krammer PH and Walczak H (2000) FADD/MORT1 and caspase-8 are recruited to TRAIL 
receptors 1 and 2 and are essential for apoptosis mediated by TRAIL receptor 2. Immunity 12: 599-609

30. Bodmer JL, Holler N, Reynard S, Vinciguerra P, Schneider P, Juo P, Blenis J and Tschopp J (2000) TRAIL receptor-2 signals apoptosis through FADD and caspase-8. Nat. Cell Biol. 2: 241-243

31. Wang J, Zheng L, Lobito A, Chan F, Dale J, Sneller M, Yao X, Puck J, Straus $S$ and Lenardo M (1999) Inherited human caspase 10 mutations underlie defective lymphocyte and dendritic cell apoptosis in autoimmune lymphoproliferative syndrome type II. Cell 98: 47-58

32. Kischkel FC, Lawrence DA, Tinel A, LeBlanc H, Virmani A, Schow P, Gazdar A, Blenis J, Arnott D and Ashkenazi A (2001) Death receptor recruitment of endogenous caspase-10 and apoptosis initiation in the absence of caspase-8. J. Biol. Chem. 276: 46639-46646

33. Green D (2000) Apoptotic pathways: paper wraps stone blunts scissors. Cell 102: $1-4$

34. Bouillet P and Strasser A (2002) BH3-only proteins - evolutionarily conserved proapoptotic Bcl-2 family members essential for initiating programmed cell death. J. Cell Sci. 115: 1567-1574

35. Li H, Zhu H, Xu C-J and Yuan J (1998) Cleavage of BID by caspase 8 mediates the mitochondrial damage in the Fas pathway to apoptosis. Cell 94: 491-501

36. Luo X, Budihardjo I, Zou H, Slaughter C and Wang X (1998) Bid, a Bcl2 interacting protein, mediates cytochrome $C$ release from mitochondria in response to activation of cell surface death receptors. Cell 94: 481-490

37. Deveraux QL, Leo E, Stennicke HR, Welsh K, Salvesen GS and Reed JC (1999) Cleavage of human inhibitor of apoptosis protein XIAP results in fragments with distinct specificities for caspases. EMBO J. 18: $5242-5251$

38. Du C, Fang M, Li Y, Li L and Wang X (2000) Smac, a mitochondrial protein that promotes cytochrome $c$-dependent caspase activation by eliminating IAP inhibition. Cell 102: 33-42

39. Verhagen AM, Ekert PG, Pakusch M, Silke J, Connolly LM, Reid GE, Moritz RL, Simpson RJ and Vaux DL (2000) Identification of DIABLO, a mammalian protein that promotes apoptosis by binding to and antagonizing IAP proteins. Cell 102: 43-53

40. Scaffidi C, Fulda S, Srinivasan A, Friesen C, Li F, Tomaselli KJ, Debatin KM, Krammer PH and Peter ME (1998) Two CD95 (APO-1/Fas) signaling pathways. EMBO J. 17: 1675-1687

41. Lindsten $T$, Ross A, King A, Zong W-X, Rathmell J, Shiels H, Ulrich E, Waymire K, Mahar P, Frauwirth K, Chen Y, Wei M, Eng V, Adelman D, Simon M, Ma A, Golden J, Evan G, Kormeyer S, MacGregor G and Thompson C (2000) The combined functions of proapoptotic Bcl-2 family members Bak and Bax are essential for normal development of multiple tissues. Mol. Cell 6 : 1389-1399

42. Wei MC, Zong W-X, Cheng EH-Y, Lindsten T, Panoutsakopoulou V, Ross AJ, Roth KA, MacGregor GR, Thompson CB and Korsmeyer SJ (2001) Proapoptotic BAX and BAK: a requisite gateway to mitochondrial dysfunction and death. Science 292: 727-730

43. Keogh SA, Walczak H, Bouchier-Hayes L and Martin SJ (2000) Failure of BCl2 to block cytochrome $c$ redistribution during TRAIL-induced apoptosis. FEBS Lett. 471: 93-98

44. Walczak H, Bouchon A, Stahl H and Krammer PH (2000) Tumor necrosis factor-related apoptosis-inducing ligand retains its apoptosis-inducing capacity on $\mathrm{Bcl}-2$ or $\mathrm{Bcl}-\mathrm{X}_{\mathrm{L}}$-overexpressing chemotherapy-resistant tumor cells. Cancer Res. 60: 3051-3057

45. Wen J, Ramadevi N, Nguyen D, Perkins C, Worthington E and Bhalla $\mathrm{K}$ (2000) Antileukemic drugs increase death receptor 5 levels and enhance Apo-2L-induced apoptosis of human acute leukemia cells. Blood 96: 3900-3906

46. Burns TF and El-Deiry WS (2001) Identification of inhibitors of TRAIL-induced death (ITIDs) in the TRAIL-sensitive colon carcinoma cell line SW480 using a genetic approach. J. Biol. Chem. 276: 37879-37886

47. LeBlanc H, Lawrence D, Varfolomeev E, Totpal K, Morlan J, Schow P, Fong S, Schwall R, Sinicropi D and Ashkenazi A (2002) Tumor cell resistance to death receptor induced apoptosis through mutational inactivation of the proapoptotic Bcl-2 homolog Bax. Nat. Med. 8: 274-281

48. Deng $Y$, Lin $Y$ and Wu $X$ (2002) TRAlL-induced apoptosis requires Bax-dependent mitochondrial release of Smac/DIABLO. Genes Dev. 16 33-45
49. Ravi R and Bedi A (2002) Requirement of BAX for TRAIL/Apo2L-induced apoptosis of colorectal cancers: synergism with Sulindac-mediated inhibition of Bcl-xL. Cancer Res. 62: 1583-1587

50. Zhang XD, Zhang XY, Gray CP, Nguyen $T$ and Hersey $P$ (2001) Tumor necrosis factor-related apoptosis-inducing ligand-induced apoptosis of human melanoma is regulated by Smac/DIABLO release from mitochondria. Cancer Res. 61: 7339-7348

51. Tschopp J, Irmler MA and Thome M (1998) Inhibition of Fas death signals by FLIPs. Curr. Opin. Immunol. 10: 552-558

52. Irmler M, Thome M, Hahne M, Schneider P, Hofmann K, Steiner V, Bodmer JL, Schröter M, Burns K, Mattmann C, Rimoldi D, French LE and Tschopp J (1997) Inhibition of death receptor signals by cellular FLIP. Nature 388: 190-195

53. Wang J, Lobito AA, Shen F, Hornung F, Winoto A and Lenardo MJ (2000) Inhibition of Fas-mediated apoptosis by the B cell antigen receptor through cFLIP. Eur. J. Immunol. 30: 155-163

54. Kim K, Fisher MJ, Xu S-Q and El-Deiry WS (2000) Molecular determinants of response to TRAIL in killing of normal and cancer cells. Clin. Cancer Res. 6: 335-346

55. Griffith TS, Chin WA, Jackson GC, Lynch DH and Kubin MZ (1998) Intracellular regulation of TRAIL-induced apoptosis in human melanoma cells. J. Immunol. 161: 2833-2840

56. Mitsiades N, Mitsiades CS, Poulaki V, Anderson KC and Treon SP (2002) Intracellular regulation of tumor necrosis factor-related apoptosis-inducing ligand-induced apoptosis in human multiple myeloma cells. Blood 99: 2162-2171

57. Petak I, Douglas L, Tillman DM, Vernes R and Houghton JA (2000) Pediatric rhabdomyosarcoma cell lines are resistant to Fas-induced apoptosis and highly sensitive to TRAIL-induced apoptosis. Clin. Cancer Res. 6: 4119-4127

58. Nimmanapalli R, Perkins CL, Orlando M, O'Bryan E, Nguyen D and Bahlla KN (2001) Pretreatment with Paclitaxel enhances Apo-2 ligand/tumor necrosis factor-related apoptosis-inducing ligand-induced apoptosis of prostate cancer cells by inducing death receptors 4 and 5 protein levels. Cancer Res. 61: 759-763

59. Lincz LF, Yeh T-X and Spencer A (2001) TRAlL-induced eradication of primary tumour cells from multiple myeloma patient bone marrows is not related to TRAIL receptor expression or prior chemotherapy. Leukemia 15: 1650-1657

60. Zhang XD, Franco AV, Nguyen T, Gray CP and Hersey P (2000) Differential localization and regulation of death and decoy receptors for TNF-related apoptosis-inducing ligand (TRAIL) in human melanoma cells. J. Immunol. 164: 3961-3970

61. Olsson A, Diaz T, Aguilar-Santelises M, Österborg A, Celsing F, Jondal M and Osorio LM (2001) Sensitization to TRAIL-induced apoptosis and modulation of FLICE-inhibitory protein in B chronic lymphocytic leukemia by actinomycin D. Leukemia 15: 1868-1877

62. Karin M and Lin A (2002) NF-kappaB at the crossroads of life and death. Nat. Immunol. 3: 221-227

63. Wu GS, Burns TF, McDonald ER, Jiang W, Meng R, Krantz ID, Kao G, Gan DD, Zhou JY, Muschel R, Hamilton SR, Spinner NB, Markowitz S, Wu G and El-Deiry W (1997) KILLER/DR5 is a DNA damage-inducible p53-regulated death receptor gene. Nat. Genet. 17: 141-143

64. Sarker M, Ruiz-Ruiz C and López-Rivas A (2001) Activation of protein kinase $\mathrm{C}$ inhibits TRAIL-induced caspases activation, mitochondrial events and apoptosis in a human leukemic $\mathrm{T}$ cell line. Cell Death Diff. 8: 172-181

65. Trauzold A, Wermann H, Arlt A, Schütze S, Schäfer H, Oestern S, Röder C, Ungefroren $\mathrm{H}$, Lampe $\mathrm{E}$, Heinrich M, Walczak $\mathrm{H}$ and Kalthoff $\mathrm{H}$ (2001) CD95 and TRAIL receptor-mediated activation of protein kinase $C$ and NF kappa-B contributes to apoptosis resistance in ductal pancreatic adenocarcinoma cells. Oncogene 20: 4258-4269

66. Tran SEF, Holmstrom TH, Ahonen M, Kahari V-M and Eriksson JE (2001) MAPK/ERK overrides the apoptotic signaling from Fas, TNF, and TRAIL receptors. J. Biol. Chem. 276: 16484-16490

67. Thakkar H, Chen X, Tyan F, Gim S, Robinson H, Lee C, Pandey SK, Nwokorie C, Onwudiwe N and Srivastava RK (2001) Pro-survival function of Akt/protein kinase B in prostate cancer cells. Relationship with TRAIL resistance. J. Biol. Chem. 276: 38361-38585 
68. Nesterov A, Lu X, Johnson M, Miller GJ, Ivashchenko Y and Kraft AS (2001) Elevated Akt activity protects the prostate cancer cell line LNCaP from TRAILinduced apoptosis. J. Biol. Chem. 276: 10767-10774

69. Kumar-Sinha C, Varambally S, Sreekumar A and Chinnaiyan AM (2001) Molecular cross-talk between the TRAIL and interferon signaling pathways. J. Biol. Chem. 277: 575-585

70. Wu G, Burns T, Zhan Y, Alnemri E and El-Deiry W (1999) Molecular cloning and functional analysis of the mouse homologue of the KILLER/DR5 tumor necrosis factor-related apoptosis-inducing ligand (TRAIL) death receptor. Cancer Res. 59: 2770-2775

71. Cretney E, Takeda K, Yagita H, Glaccum M, Peschon JJ and Smyth MJ (2002) Increased susceptibility to tumor initiation and metastasis in TNF-related apoptosis-inducing ligand-deficient mice. J. Immunol. 168: 1356-1361

72. Takeda K, Hayakawa Y, Smyth MJ, Kayagaki N, Yamaguchi N, Kakuta S, Iwakura Y, Yagita H and Okumura K (2001) Involvement of tumor necrosis factor-related apoptosis-inducing ligand in surveillance of tumor metastasis by liver natural killer cells. Nat. Med. 7: 94-100

73. Takeda K, Smyth MJ, Cretney E, Hayakawa $\mathrm{Y}$, Kayagaki N, Yagita $\mathrm{H}$ and Okumura K (2002) Critical role for tumor necrosis factor-related apoptosisinducing ligand in immune surveillance against tumor development. J. Exp. Med. 195: 161-169

74. Gong B and Almasan A (2000) Genomic organization and transcriptiona regulation of human Apo2/TRAIL gene. BBRC 278: 747-752

75. Sato K, Hida S, Takayanagi H, Yokochi T, Kayagaki N, Takeda K, Yagita H, Okumura K, Tanaka N, Taniguchi T and Ogasawara K (2001) Antivira response by natural killer cells through TRAIL gene induction by IFN- $\alpha / \beta$. Eur. J. Immunol. 31: 3138-3146

76. Sedger LM, Shows DM, Blanton RA, Peschon JJ, Goodwin RG, Cosman D and Wiley SR (1999) IFN- $\gamma$ mediates a novel antiviral activity through dynamic modulation of TRAIL and TRAIL receptor expression. J. Immunol. 163: 920-926

77. Griffith T, Wiley S, Kubin M, Sedger L, Maliszewski C and Fanger N (1999) Monocyte-mediated tumoricidal activity via the tumor necrosis factor-related cytokine, TRAIL. J. Exp. Med. 189: 1343-1353

78. Johnsen AC, Haux J, Steinkjer B, Nonstad U, Egeberg K, Sundan A, Ashkenazi A and Espevik T (1999) Regulation of APO-2 ligand/trail expression in NK cells-involvement in NK cell-mediated cytotoxicity. Cytokine 11: 664-672

79. Kayagaki N, Yamaguchi N, Nakayama M, Eto $H$, Okumura $\mathrm{K}$ and Yagita $\mathrm{H}$ (1999) Type I interferons (IFNs) regulate tumor necrosis factor-related apoptosis-inducing ligand (TRAIL) expression on human T cells: a novel mechanism for the antitumor effects of Type I IFNs. J. Exp. Med. 189: 1451-1460

80. Chen $Q$, Gong B, Mahmoud-Ahmed AS, Zhou A, Hsi ED, Hussein M and Almasan A (2001) Apo2L/TRAIL and Bcl-2-related proteins regulate type I interferon-induced apoptosis in multiple myeloma. Blood 98: 2183-2192

81. Lu G, Janjic BM, Janjic J, Whiteside TL, Storkus WJ and Vujanovic NL (2002) Innate direct anticancer effector function of human immature dendritic cells. II. Role of TNF, lymphotoxin- $\alpha 1 \beta 2$, Fas ligand, and TNF-related apoptosisinducing ligand. J. Immunol. 168: 1831-1839

82. Vidalain P-O, Azocar O, Lamouille B, Astier A, Rabourdin-Combe C and Servet-Delprat $C$ (2000) Measles virus induces functional TRAIL production by human dendritic cells. J. Virol. 74: 556-559

83. Monleon I, Martinez-Lorenzo MJ, Monteagudo L, Lasierra P, Taules M Iturralde M, Pineiro A, Larrad L, Alava MA, Naval J and Anel A (2001) Differential secretion of Fas ligand- or APO2 ligand/TNF-related apoptosisinducing ligand-carrying microvesicles during activation-induced death of human T cells. J. Immunol. 167: 6736-6744

84. Song K, Chen Y, Goke R, Wilmen A, Seidel C, Goke A, Hilliard B and Chen Y (2000) Tumor necrosis factor-related apoptosis-inducing ligand (TRAIL) is an inhibitor of autoimmune inflammation and cell cycle progression. J. Exp. Med 191: 1095-1104

85. Hilliard B, Wilmen A, Seidel C, Liu T-ST, Goke R and Chen Y (2001) Roles of TNF-related apoptosis-inducing ligand in experimental autoimmune encephalomyelitis. J. Immunol. 166: 1314-1319

86. Mitsiades CS, Treon SP, Mitsiades N, Shima Y, Richardson P, Schlossman R Hideshima T and Anderson KC (2001) TRAIL/Apo2L ligand selectively induces apoptosis and overcomes drug resistance in multiple myeloma: therapeutic applications. Blood 98: 795-804

87. Ashkenazi A and Dixit VM (1999) Apoptosis control by death and decoy receptors. Curr. Opin. Cell Biol. 11: 255-260

88. Kelley SK, Harris LA, Xie D, DeForge L, Totpal K, Bussiere J and Fox JA (2001) Preclinical studies to predict the disposition of Apo2L/tumor necrosis factor-related apoptosis-inducing ligand in humans: characterization of in vivo efficacy, pharmacokinetics, and safety. J. Pharmacol. Exp. Ther. 299: 31-38

89. Roth W, Isenmann S, Naumann U, Kugler S, Bahr M, Dichgans JA and Weller M (1999) Locoregional Apo2L/TRAIL eradicates intracranial human malignant glioma xenografts in a thymic mice in the absence of neurotoxicity. Biochem. Biophys. Res. Commun. 265: 479-483

90. Pollack IF, Erff M and Ashkenazi A (2001) Direct stimulation of apoptotic signaling by soluble Apo2L/tumor necrosis factor-related apoptosis-inducing ligand leads to selective killing of glioma cells. Clin. Cancer Res. 7: 1362-1369

91. Gliniak B and Le T (1999) Tumor necrosis factor-related apoptosis-inducing ligand's antitumor activity in vivo is enhanced by the chemotherapeutic agent CPT-11. Cancer Res. 59: 6153-6158

92. Chinnaiyan AM, Prasad U, Shankar S, Hamstra DA, Shanaiah M, Chenevert TL, Ross BD and Rehemtulla A (2000) Combined effect of tumor necrosis factor-related apoptosis-inducing ligand and ionizing radiation in breast cancer therapy. Proc. Natl. Acad. Sci. USA 97: 1754-1759

93. Chuntharapai A, Dodge K, Grimmer K, Schroeder K, Marsters SA, Koeppen $\mathrm{H}$, Ashkenazi A and Kim KJ (2001) Isotype-dependent inhibition of tumor growth in vivo by monoclonal antibodies to death receptor 4. J. Immunol. 166 : 4891-4898

94. Ichikawa K, Liu W, Zhao L, Wang Z, Liu D, Ohtsuka T, Zhang H, Mountz JD, Koopman WJ, Kimberly RP and Zhou T (2001) Tumoricidal activity of a nove anti-human DR5 monoclonal antibody without hepatocyte cytotoxicity. Nat. Med. 7: 954

95. Trauth BC, Klas C, Peters AMJ, Matzku S, Moller P, Falk W, Debatin KM and Krammr PH (1989) Monoclonal antibody-mediated tumor regression by induction of apoptosis. Science 245: 301-304

96. Muhlenbeck F, Schneider P, Bodmer J-L, Schwenzer R, Hauser A, Schubert G, Scheurich P, Moosmayer D, Tschopp J and Wajant H (2000) The tumor necrosis factor-related apoptosis-inducing ligand receptors TRAIL-R1 and TRAIL-R2 have distinct cross-linking requirements for initiation of apoptosis and are non-redundant in JNK activation. J. Biol. Chem. 275: 32208-32213

97. Lee SH, Shin MS, Kim HS, Lee HK, Park WS, Kim SY, Lee JH, Han SY, Park JY, Oh RR, Kang CS, Kim KM, Jang JJ, Nam SW, Lee JY and Yoo NJ (2001) Somatic mutations of TRAIL-receptor 1 and TRAIL-receptor 2 genes in nonHodgkin's lymphoma. Oncogene 20: 399-403

98. Lee SH, Shin MS, Kim HS, Lee HK, Park WS, Kim SY, Lee JH, Han SY, Park JY, Oh RR, Jang JJ, Han JY, Lee JY and Yoo NJ (1999) Alterations of the DR5/TRAIL receptor 2 gene in non-small cell lung cancers. Cancer Res. 59: 5683-5686

99. Arai T, Akiyama Y, Okabe S, Saito K, Iwai T and Yuasa Y (1998) Genomic organization and mutation analyses of the DR5/TRAIL receptor 2 gene in colorectal carcinomas. Cancer Lett. 133: 197-204

100. Shin MS, Kim HS, Lee SH, Park WS, Kim SY, Park JY, Lee JH, Lee SK, Lee SN, Jung SS, Han JY, Kim H, Lee JY and Yoo NJ (2001) Mutations of tumor necrosis factor-related apoptosis-inducing ligand receptor 1 (TRAIL-R1) and receptor 2 (TRAIL-R2) genes in metastatic breast cancers. Cancer Res. 61 : 4942-4946

101. Pai S, Wu G, Ozoren N, Wu L, Jen J, Sidransky D and El-Deiry W (1998) Rare loss-of-function mutation of a death receptor gene in head and neck cancer. Cancer Res. 58: 3513-3518

102. Perucho M (1996) Cancer of the microsatellite mutator phenotype. Biol. Chem. 377: 675-684

103. Gayet J, Zhou X-P, Duval A, Rolland S, Hoang J-M, Cottu P and Hamelin R (2001) Extensive characterization of genetic alterations in a series of human colorectal cancer cell lines. Oncogene 20: 5025-5032

104. Rampino N, Yamamoto H, Lonov Y, Li Y, Sawai H, Reed J and Perucho M (1997) Somatic frameshift mutations in the BAX gene in colon cancers of the microsatellite mutator phenotype. Science 275: 967-969 
105. Ionov Y, Yamamoto H, Krajewski S, Reed JC and Perucho M (2000) Mutational inactivation of the proapoptotic gene Bax confers selective advantage during tumor clonal evolution. Proc. Natl. Acad. Sci. USA 97: 10872-10877
106. Zhou Q, Fukushima P, DeGraff W, Mitchell JB, Stetler-Stevenson M, Ashkenazi A and Steeg PS (2000) Radiation and the Apo2L/TRAIL apoptotic pathway preferentially inhibit the colonization of premalignant human breast cells overexpressing cyclin D1. Cancer Res. 60: 2611-2615 